\title{
Tulane
}

\author{
Tulane Economics Working Paper Series
}

\section{Deconstructing the Decline in Inequality in Latin America}

\author{
Nora Lustig, Coordinator \\ Department of Economics \\ Tulane University \\ New Orleans, Louisiana \\ nlustig@tulane.edu
}

\author{
Luis F. Lopez-Calva \\ Lead Economist, Poverty and \\ Gender Unity, Latin America and \\ the Caribbean Vice-presidency \\ World Bank \\ Washington, DC \\ Iflopezcalva@worldbank.org
}

\author{
Eduardo Ortiz-Juarez \\ Economist, Poverty, Human \\ Development and Millennium \\ Development Goal Unit, Regional \\ Bureau for Latin America and the \\ Caribbean \\ United Nations Development \\ Programme (UNDP) \\ New York, New York \\ eduardo.ortiz@undp.org \\ Working Paper 1314 \\ April 2013
}

\begin{abstract}
Inequality in Latin America unambiguously declined in the 2000s. The Gini coefficient fell in 14 of the 17 countries where there is comparable data, and the change was statistically significant for all of them. Existing studies point to two main explanations for the decline in inequality: a reduction in hourly labor income inequality, and more robust and progressive government transfers. Available evidence suggests that it is the skill premium -or, more precisely, the returns to primary, secondary and tertiary education vs. no schooling or incomplete primary schooling- that drives the decline in hourly labor income inequality. The causes behind the decline in returns to schooling, however, have not been unambiguously established. Some studies find that returns fell because of an increase in the supply of workers with more educational attainment; others, because of a shift in demand away from skilled-labor.
\end{abstract}

Keywords: inequality, skill premium, government transfers, Latin America JEL: Keywords: D31, 124, H53, O15, O54 


\title{
Deconstructing the Decline in Inequality in Latin America1
}

\author{
Nora Lustig, Luis F. Lopez-Calva and Eduardo Ortiz-Juarez ${ }^{2}$
}

April 3, 2013

\begin{abstract}
Inequality in Latin America unambiguously declined in the 2000s. The Gini coefficient fell in 14 of the 17 countries where there is comparable data, and the change was statistically significant for all of them. Existing studies point to two main explanations for the decline in inequality: a reduction in hourly labor income inequality, and more robust and progressive government transfers. Available evidence suggests that it is the skill premium -or, more precisely, the returns to primary, secondary and tertiary education vs. no schooling or incomplete primary schooling-- that drives the decline in hourly labor income inequality. The causes behind the decline in returns to schooling, however, have not been unambiguously established. Some studies find that returns fell because of an increase in the supply of workers with more educational attainment; others, because of a shift in demand away from skilled-labor.
\end{abstract}

Keywords: Inequality, skill premium, government transfers, Latin America

JEL Codes: D31, I24, H53, O15, O54

\footnotetext{
1 Chapter in Devlin, Robert, Jose Luis Machinea and Oscar Echeverria Latin American Development in an Age of Globalization: Essays in Honor of Enrique V. Iglesias.

${ }^{2}$ Nora Lustig (nlustig@tulane.edu) is Samuel Z. Stone Professor of Latin American Economics at Tulane University and nonresident fellow at the Center for Global Development and Inter-American Dialogue; Luis Felipe Lopez-Calva (lflopezcalva@worldbank.org) is the Lead Economist for the Poverty and Gender Unit, Latin America and the Caribbean at the World Bank; and Eduardo Ortiz-Juarez (eduardo.ortiz@undp.org) is Economist at the UNDP's Regional Bureau for Latin America and the Caribbean, and Non-resident Associate Research Fellow at the Center for Inter-American Policy and Research, Tulane University.
} 


\section{Inequality in Latin America Unambiguously Declined in the 2000s}

There is substantial evidence suggesting that inequality in Latin America unambiguously declined in the majority of countries in the $2000 \mathrm{~s}^{3}{ }^{3}$ From a weighted average of 0.549 in the late 1990s, the Gini coefficient for household per capita income fell to 0.498 in the late 2000s. While during this period inequality in other regions of the world rose, the Gini coefficient declined in 14 of the 17 Latin American countries for which there is comparable (Figure 1). The decline is statistically significant in all fourteen countries. ${ }^{4}$

Figure 1: Declining income inequality in Latin America, by country: 2000-2010 Annual \% change in the Gini coefficient

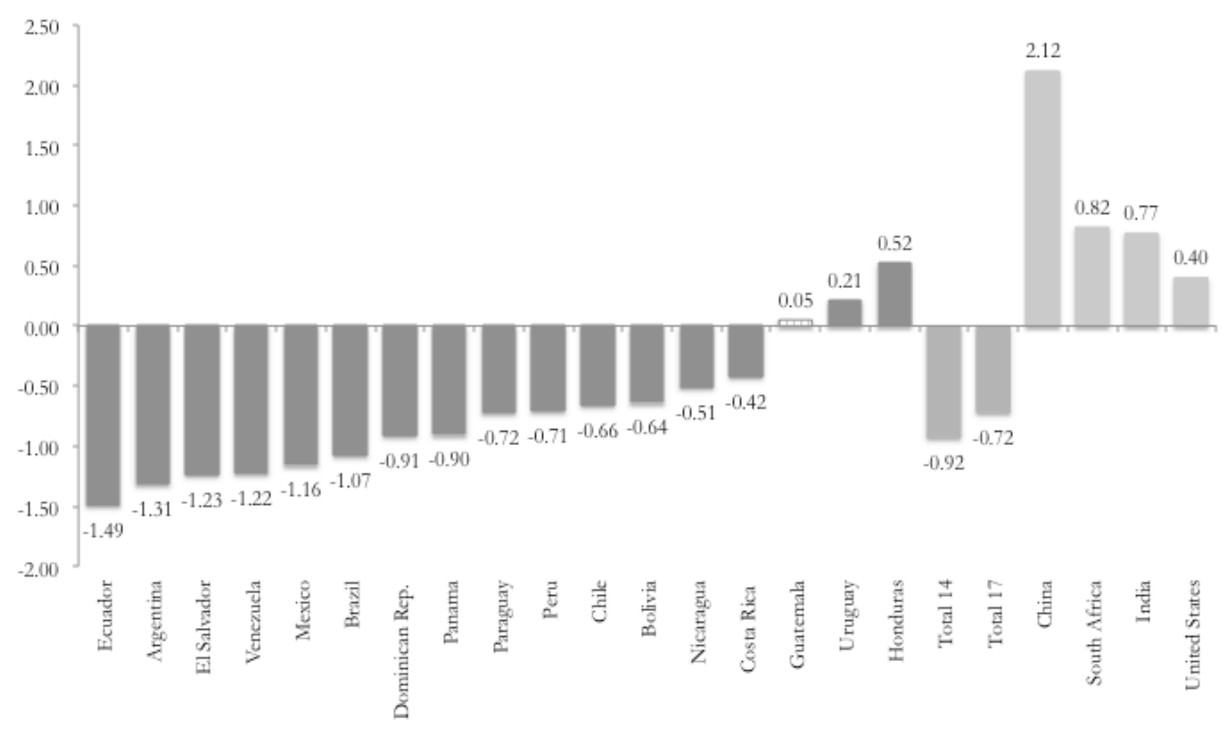

Source: Authors' calculations, based on data from SEDLAC (CEDLAS and The World Bank), March 2012 for Latin American countries; World Bank (World Development Indicators) for China, India, and South Africa; and OECD (OECD Stats) for the United States. Note: Data for Argentina and Uruguay are for urban areas only. In Uruguay, urban areas covered by the survey represent 80 percent of the total population; in Argentina, they represent 66 percent. The average change in the Gini for each country is calculated as the percentage change between the end year and the initial year, divided by the number of years. The average for the total is the simple average of the changes by country (fourteen countries in which inequality fell). The following time periods were used to estimate the percentage changes: Argentina (2000-11), Bolivia (2001-08), Brazil (2001-09), Chile (2000-09), Costa Rica (2001-10), Dominican Republic (2000-10), Ecuador (2003-10), El Salvador (2000-10), Guatemala (2000-06), Honduras (2001-10), Mexico (2000-10), Nicaragua (1998-2005), Panama (2001-10), Paraguay (2001-10), Peru (2000-10), Uruguay (2000-10), and Venezuela (2000-10). Using

\footnotetext{
${ }^{3}$ See, for example, Azevedo et al. (2012); Azevedo et al. (2013); Cornia (2013); Cruces et al. (2011); Gasparini et al. (2011); Gasparini and Lustig (2011); Lopez-Calva and Lustig (2010); and Lustig et al. (2013), who also suggest that the decline in inequality during the 2000 s is robust to the selection of income definition, inequality measure, and data source.

${ }^{4}$ Colombia is excluded from the regional averages and from the changes shown in Figure 1 due to problems of data comparability across years. In Uruguay, although inequality increases over the analyzed decade, the Gini coefficient has been on its decline since 2007.
} 
the bootstrap method, with a 95 percent significance level, the changes were not found to be statistically significant in Guatemala (represented by a grid bar in the figure). The periods used for non-Latin American countries are as follows: China (1996-2005), India (1994-2005), South Africa (1995-2009), and United States (1995-2007).

The decline is also significant in terms of orders of magnitude. As shown in Figure 2 , in the eleven countries for which the comparison is possible, the decline in the $2000 \mathrm{~s}$ was higher than the increase in inequality during the 1990s. The global recession in 2008/09 did not change the downward trend in most countries.

\section{Figure 2: The rise and fall of income inequality}

Changes in Gini coefficients, expressed in percentage points

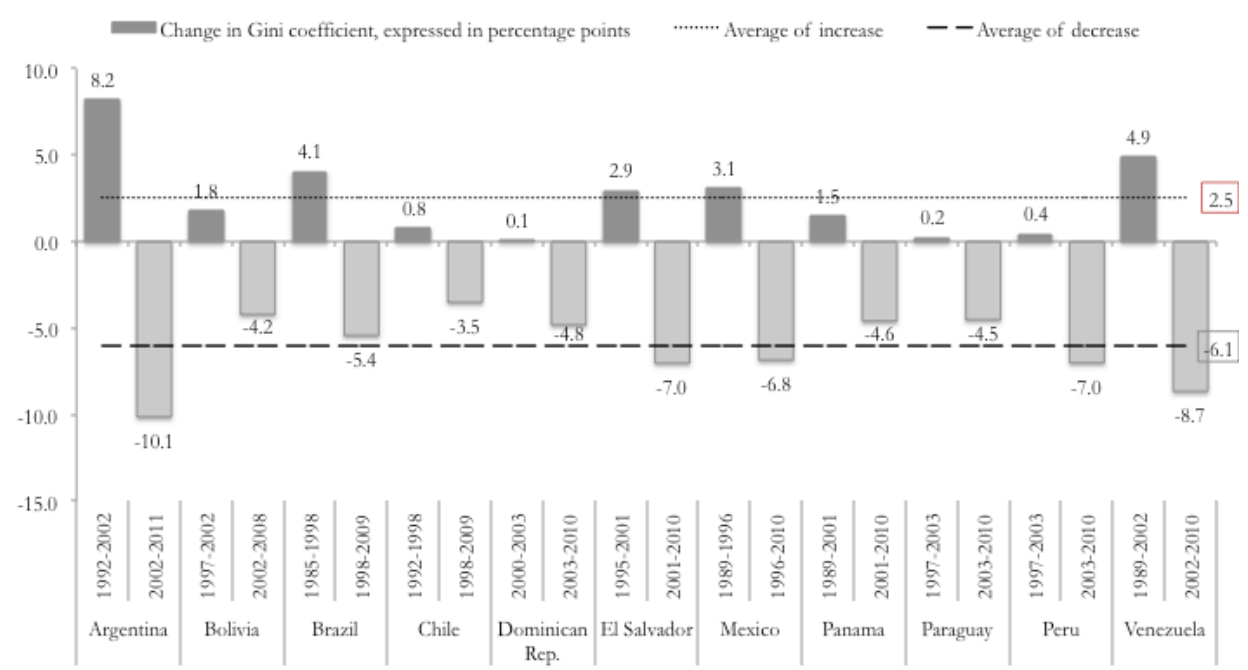

Source: Authors' calculations, based on data from SEDLAC (CEDLAS and The World Bank), March 2012. Note: The percentage-point change in the Gini coefficient, before and after inequality started to decline. Although inequality in Ecuador started to decline in 2003, no comparable data were available for earlier years.

Another indication of the quantitative significance of the decline in inequality is its contribution toward reducing poverty. Since 2000, the incidence of extreme poverty (i.e, the percentage of the population earning daily incomes of USD $\$ 2.50$ in purchasing power parity, PPP, or less) has dropped from 24.9 to 16.3 percent (a reduction of 38 million people) (Figure 3). During the same period, the incidence of total poverty -- defined as those earning below USD \$4.00 PPP per day -- fell from 41.5 to 29.6 percent (a reduction of roughly 49 million people). Applying the Datt-Ravallion decomposition approach (Datt and Ravallion 1992) reveals that, on average, 32 percent of the reduction in poverty is due to the decline in inequality. In Argentina, Bolivia, Brazil, Chile, Ecuador, Mexico, Panama and Paraguay, the decline in inequality accounted for between 40 and 89 percent of the reduction in poverty (Figure 4). 
Figure 3: Poverty in Latin America, 1992-c.2010

\section{Percentage of population}

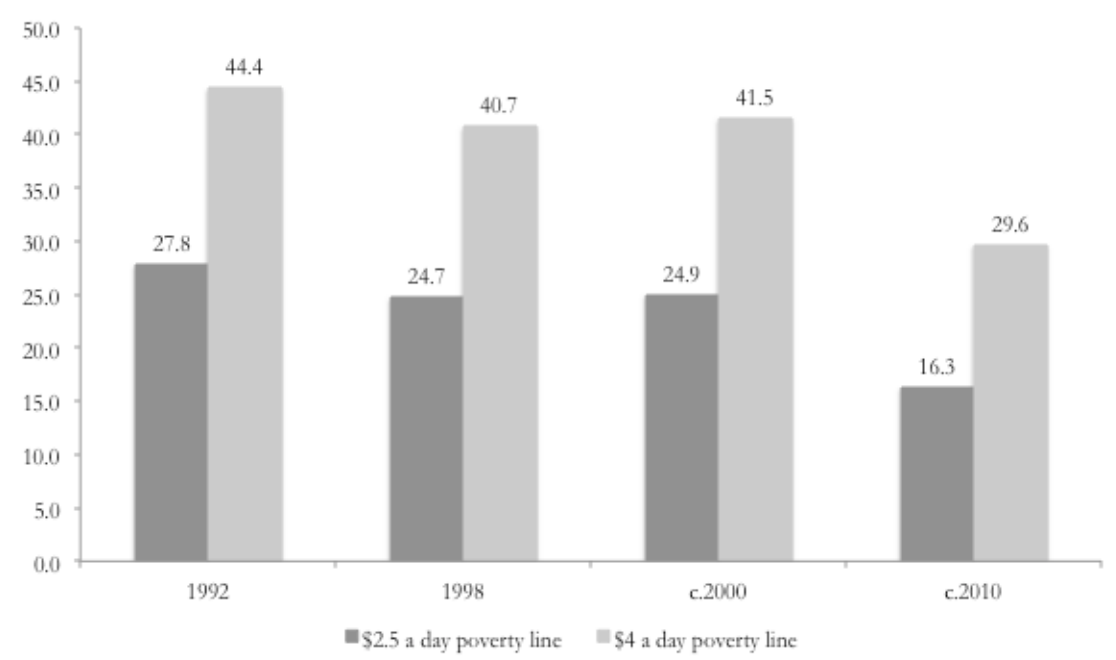

Source: Based on data from SEDLAC (CEDLAS and The World Bank), March 2012. Note: These figures represent the weighted average of the incidence of poverty in Argentina, Bolivia, Brazil, Chile, Colombia, Costa Rica, Dominican Republic, Ecuador, El Salvador, Guatemala, Honduras, Mexico, Nicaragua, Panama, Paraguay, Peru, Uruguay, and Venezuela.

\section{Figure 4: Contribution of the decline in income inequality to changes in poverty}

Selected countries; 2000 s

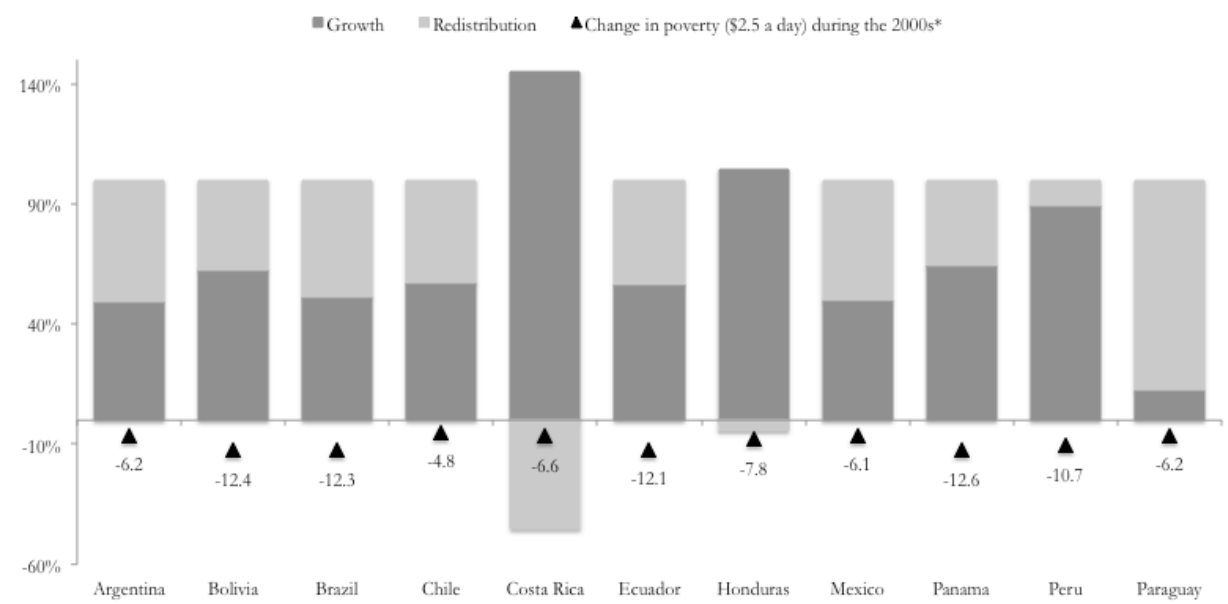

Source: Authors' calculations, based on household surveys for the Datt-Ravallion decomposition, and on data from SEDLAC (CEDLAS and The World Bank), March 2012, for the changes in the incidence of poverty. Note: The contribution which the decline in inequality made toward reducing poverty was calculated using the standard Datt-Ravallion decomposition methodology (Datt and Ravallion 1992). The following time periods were used: Argentina (2000-2009), Bolivia (2000-2008), Brazil (2001-2009), Chile (2000-2009), Costa Rica (2000-2009), Ecuador (2003-2009), Honduras (1999-2009), Mexico (2000-2008), Panama (2001-2009), Peru (2000-2009), and Paraguay (1999-2009). Note that the Dominican Republic, El Salvador, and Uruguay were not included because the residuals were extremely high, indicating unstable results. Including them would have caused a significant upward 'bias' in the estimated contribution attributable to the decline in inequality. * Percentage points of change in the incidence of poverty, as measured by the $\$ 2.5$ a day international poverty line. 


\section{The equalizing role of declining skill premiums and government cash transfers}

Disentangling the principal determinants of the decline in inequality in Latin America during the 2000s is not a straightforward task. Interestingly, there is no clear link between the decline in inequality and economic growth. Inequality has declined in countries which have experienced rapid economic growth, such as Chile, Panama and Peru, and in countries with low-growth spells, such as Brazil and Mexico. Nor is there a link between falling inequality and the orientation of political regimes. Inequality has declined in countries governed by leftist regimes, such as Argentina, Bolivia, Brazil, Chile and Venezuela, and in countries governed by centrist and center-right parties, such as Mexico and Peru.

Existing studies point to two main explanations for the decline in inequality: a reduction in hourly labor income inequality, and more robust and progressive government transfers (Azevedo et al., 2012; Cornia, 2013; De la Torre et al., 2012; López-Calva and Lustig, 2010; Lustig et al., 2013).

Applying a variation of the nonparametric decomposition method developed by Barros et al. (2006) to quantify the contributions to observed distributional changes, ${ }^{5}$ Azevedo et al. (2012) explore whether the recent decline in income inequality is the result of changes in demographics, earnings and employment, or public transfers and pensions. Their main finding is that, for the majority of the fourteen countries included in their study, the most important factor has been relatively strong growth in labor income for workers at the bottom of the income distribution, and in particular, an increase in hourly earnings. On average, 45 percent of the reduction in the Gini coefficient can be attributed to changes in hourly labor income, which has ranged from 22 percent in Panama to 66 percent in Ecuador. In terms of the contributions of non-labor incomes, changes in government transfers contributed, on average, 14 percent of the observed regional decline in inequality,

\footnotetext{
${ }^{5}$ The methodology developed by Barros et al. (2006) identifies the contribution that interactions between variables make in terms of changes in welfare, first by computing the joint impact of a subset of variables, and then subtracting the marginal impact of each variable. The simulation of a given factor therefore ends up being a "residual". In contrast, Azevedo et al. (2012) compute a cumulative counterfactual distribution by adding one variable at a time, so that the impact of changes in each variable and its interactions with all other variables is calculated as the difference between the cumulative counterfactuals. According to the authors, the advantage of this variation is that it avoids attributing the residual to the last variable considered and allows for a more straightforward interpretation of the results. Since this approach may suffer from pathdependence, they remedy this by calculating the decomposition across all possible paths and then take the average between them. These averages constitute the Shapley-Shorrocks estimates of each component.
} 
while changes in pensions contributed 7 percent. There is, however, substantial heterogeneity across countries (Table 1$)^{6}$.

Table 1: Contributions to the decline in the Gini coefficient

Percentages of contributions

\begin{tabular}{|c|c|c|c|c|c|c|c|c|c|}
\hline & $\begin{array}{c}\text { Adult } \\
\text { population }\end{array}$ & $\begin{array}{c}\text { Occupation } \\
\text { Share }\end{array}$ & $\begin{array}{l}\text { Hours } \\
\text { worked }\end{array}$ & $\begin{array}{c}\text { Labor } \\
\text { income per } \\
\text { hour }\end{array}$ & Capital & Pensions & Transfers & $\begin{array}{l}\text { Other non- } \\
\text { labor }\end{array}$ & Residual \\
\hline Argentina & $14 \%$ & $7 \%$ & $13 \%$ & $33 \%$ & $-1 \%$ & $14 \%$ & $7 \%$ & $-14 \%$ & $28 \%$ \\
\hline Brazil & $12 \%$ & $0 \%$ & $-3 \%$ & $41 \%$ & $0 \%$ & $14 \%$ & $13 \%$ & $7 \%$ & $15 \%$ \\
\hline Chile & $18 \%$ & $-8 \%$ & $-4 \%$ & $29 \%$ & $5 \%$ & $16 \%$ & $34 \%$ & $-26 \%$ & $35 \%$ \\
\hline Colombia & $10 \%$ & $10 \%$ & $13 \%$ & $45 \%$ & $-4 \%$ & $-5 \%$ & $25 \%$ & $18 \%$ & $-12 \%$ \\
\hline Costa Rica & $28 \%$ & $-19 \%$ & $-10 \%$ & $-77 \%$ & $10 \%$ & $-6 \%$ & $18 \%$ & $-36 \%$ & $-9 \%$ \\
\hline Dominican Rep. & $9 \%$ & $-13 \%$ & $-11 \%$ & $24 \%$ & $4 \%$ & $2 \%$ & $38 \%$ & $-3 \%$ & $50 \%$ \\
\hline Ecuador & $13 \%$ & $-4 \%$ & $2 \%$ & $66 \%$ & $2 \%$ & $-2 \%$ & $15 \%$ & $6 \%$ & $1 \%$ \\
\hline El Salvador & $15 \%$ & $-5 \%$ & $-3 \%$ & $41 \%$ & $3 \%$ & $-1 \%$ & $11 \%$ & $15 \%$ & $25 \%$ \\
\hline Honduras & $26 \%$ & $-33 \%$ & $38 \%$ & $-91 \%$ & $5 \%$ & $-7 \%$ & $12 \%$ & $-20 \%$ & $-31 \%$ \\
\hline Mexico & $13 \%$ & $-9 \%$ & $-6 \%$ & $64 \%$ & $3 \%$ & $3 \%$ & $13 \%$ & $22 \%$ & $-3 \%$ \\
\hline Panama & $6 \%$ & $6 \%$ & $13 \%$ & $22 \%$ & $-1 \%$ & $10 \%$ & $24 \%$ & $0 \%$ & $20 \%$ \\
\hline Paraguay & $20 \%$ & $2 \%$ & $10 \%$ & $-64 \%$ & $0 \%$ & $-3 \%$ & $2 \%$ & $0 \%$ & $132 \%$ \\
\hline Peru & $0 \%$ & $-1 \%$ & $7 \%$ & $37 \%$ & $-1 \%$ & $1 \%$ & $0 \%$ & $26 \%$ & $31 \%$ \\
\hline Uruguay & $24 \%$ & $45 \%$ & $-14 \%$ & $-114 \%$ & $-1 \%$ & $-60 \%$ & $110 \%$ & $-128 \%$ & $39 \%$ \\
\hline LAC-14 & $12 \%$ & $-2 \%$ & $0 \%$ & $45 \%$ & $1 \%$ & $7 \%$ & $14 \%$ & $11 \%$ & $13 \%$ \\
\hline
\end{tabular}

Source: Azevedo et al., (2012), based on data from SEDLAC (CEDLAS and The World Bank).

The key question then becomes: What explains the reduction in hourly labor income inequality? In line with the explanations submitted by Lopez-Calva and Lustig (2010) and Gasparini and Lustig (2011), available evidence suggests that it is the skill premium --or, more precisely, the returns to education-- that drives the decline in hourly labor income inequality (Azevedo et al., 2013; Barros et al., 2010; Campos et al., 2012; de la Torre et al., 2012; Gasparini and Cruces, 2010). In particular, during the 2000s, in the majority of the fourteen countries where overall inequality declined, the return to primary, secondary and tertiary education vs. no schooling or incomplete primary schooling declined. In Ecuador, Brazil, Paraguay, Peru and Chile, the return declined for all levels of education, vis-à-vis no schooling or incomplete primary, while in Costa Rica a decline was reported only for the return to primary education vs. no schooling or incomplete primary.

Results are more mixed for the remaining countries (Figure 5).

Figure 5: Changes in the Gini coefficient and in the return to education; 2000-2010 Annual \% change

\footnotetext{
${ }^{6}$ Azevedo et al. (2012), however, include noncontributory pensions as part of pensions, so their analysis may somewhat underestimate the role of government transfers in explaining the decline in inequality. As shown by Lustig and Pessino (2013) for Argentina, the large expansion of noncontributory pensions was fundamental in accounting for the reduction in inequality during 2006-2009.
} 


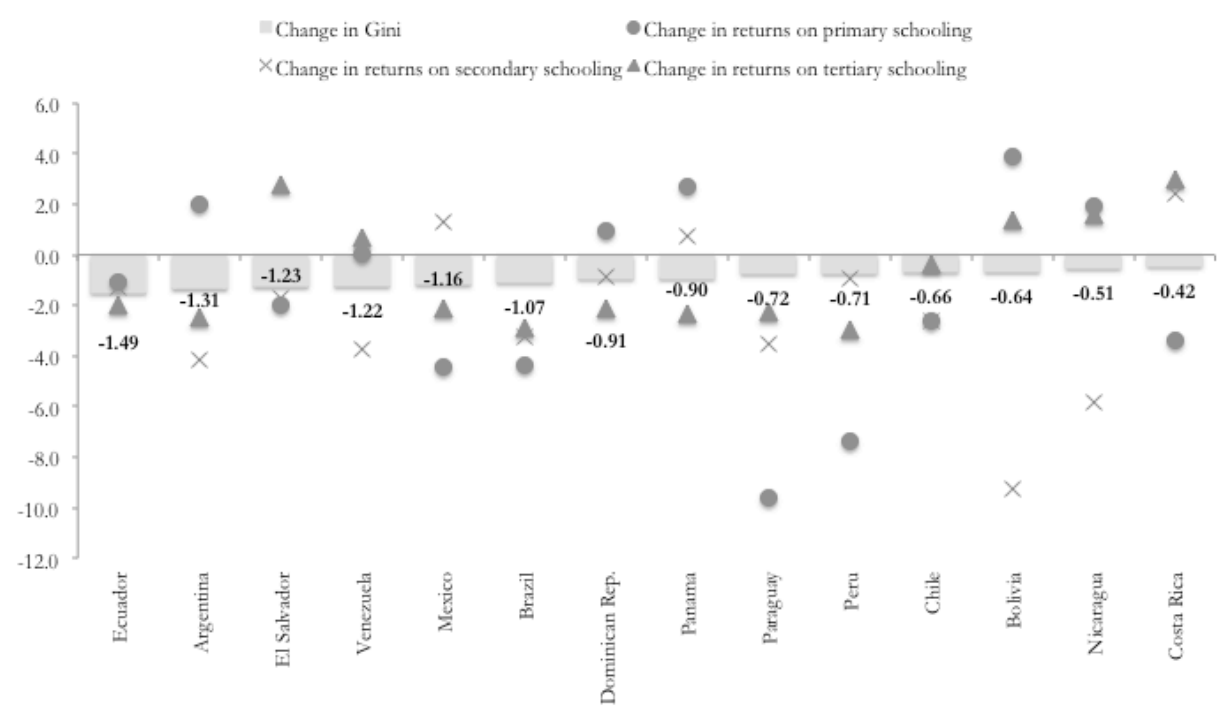

Source: Authors' calculations, based on data from SEDLAC (CEDLAS and The World Bank), March 2012. Note: The returns to different levels of education are calculated with respect to no schooling or incomplete primary school. Skill categories are determined by level of formal education. Educational levels correspond to completed primary school, lower- and upper-secondary school, and tertiary education. The time periods used to estimate the percentage changes are the same as those used in Figure 1.

Cornia's analysis (2013) confirmed most of the previous evidence for six countries: Chile, Ecuador, El Salvador, Honduras, Mexico and Uruguay. In particular, his findings show that changes in labor income explain a significant share of the shift in income inequality observed during the 2000s, and that the upward (during the 1990s) or downward (during the 2000s) trends in labor income were accompanied in most cases by parallel shifts in the skill premium.

It should be noted that although the distribution of educational attainment has become more equal, this change has had an unequalizing effect (Campos et al.; Gasparini et al., 2011). What this means is that had the skill premium remained unchanged during this specific period, educational upgrading would have been unequalizing. Because this sounds counter-intuitive, this finding is known as the "paradox of progress." Essentially, it is a byproduct of the convexity of returns. (See Bourguignon et al. 2005, for a detailed explanation). Eventually, as the dispersion of years of schooling becomes smaller and smaller, this paradoxical result will disappear.

The determinants of the decline in non-labor income inequality include: returns to capital (interests, profits and rents), private transfers (for example, remittances) and public transfers. The contribution of changes in returns to capital in Argentina, Brazil and Mexico, 
for example, tended to be small and unequalizing (Lustig et al. 2013). However, a wellknown fact is that household surveys under-estimate income from capital so the unequalizing effect may have been larger than current estimates indicate. Esquivel et al. (2010) show that, in Mexico, remittances proved to be equalizing and became even more so in the 2000s, because they closed the gap between rural and urban household per capita incomes. Cornia (2013) also shows that the increase in migrant remittances in total household income appears to have had an equalizing effect in El Salvador and Mexico; however, in Honduras their effect was unequalizing.

As mentioned above, Azevedo et al. (2012) find that, on average, government transfers account for 14 percent of the decline in overall inequality. However, these authors include noncontributory pensions as part of pensions (which account, on average, for 7 percent of the decline). Their analysis, therefore, may underestimate the role of government transfers in explaining the decline in inequality. For example, Lustig and Pessino (2013) show that for Argentina, the large expansion in noncontributory pensions was fundamental in accounting for the reduction in inequality during 2006-2009. In the case of Brazil, Barros et al. (2010) find that for the period 2001 - 2007, changes in the size, coverage and distribution of public transfers account for 49 percent of the decline in inequality, and in the case of Mexico, Esquivel et al. (2010) find that these factors account for 18 percent of the decline in inequality for the period 1996-2006.

\section{The causes of the decline in the returns to education}

Existing studies suggest that one of the main factors underlying the decline in income inequality was the decline in the returns to education, often called the skill premium. Why did the returns to education decline? This is where accounts begin to differ. There are four potential (and not mutually exclusive) explanations for this phenomenon: a reduction in the relative demand for skilled workers; an increase in the relative supply of skilled workers; an increase in minimum wages and unionization rates benefiting low-wage workers more than high-wage workers; and a degradation of tertiary education. The latter could occur due to a combination of an expansion of tertiary education of lower quality and/or because those entering expanded tertiary education programs increasingly include individuals with lower abilities, as compared to previous patterns of human capital accumulation. 
Lopez-Calva and Lustig (2010) posit that the most important factor behind the decline in the returns to education has been an increase in the relative supply of workers with completed secondary and tertiary education, a result of the significant educational upgrading that took place in the region during the 1990s (Cruces et al., 2011). This conclusion is also supported by Azevedo et al. (2013), who suggest that the decline in the skill premium has been driven by an increase in the supply of experienced and educated workers in the region. In Brazil and Mexico, Barros et al. (2010), and Esquivel et al. (2010) and Campos et al. (2012), respectively, show that there have been notable changes in the composition of the labor supply, and an increase in the relative supply of skilled workers seems to dominate as a factor explaining the decline in the skill premium. In Argentina (Gasparini and Cruces, 2010), the reduction in the skill premium appears to be related not just to the change in the composition of labor by skills, but also to the employment effects of a booming economy and the wage-compressing effects of active labor market policies implemented by a pro-union government.

The expansion of basic education that underlies the change in labor composition by skill in Brazil and Mexico, in turn, seems to be associated with higher public spending per student in basic education and an increase in education coverage in rural areas. These factors eased supply-side constraints. In addition, the conditional cash transfer programs Bolsa Família (Brazil) and Progresa/Oportunidades (Mexico) reduced demand-side constraints by compensating poor households for schooling costs and for the opportunity cost of children's labor. 7 A summary of these findings can be found in Table 2.

Table 2: Summary of results suggesting that the fall in the skill premium is the result of an increase in the supply of skilled workers

\begin{tabular}{|c|c|c|c|}
\hline Study & Country coverage & $\begin{array}{l}\text { Countries where } \\
\text { supply-side factors } \\
\text { dominate }\end{array}$ & Results \\
\hline $\begin{array}{l}\text { Azevedo et al. } \\
\text { (2013) }\end{array}$ & $\begin{array}{l}\text { Argentina, Bolivia, } \\
\text { Brazil, Chile, } \\
\text { Colombia, Costa Rica, } \\
\text { Dominican Republic, } \\
\text { Ecuador, El Salvador, } \\
\text { Honduras, Mexico, } \\
\text { Panama, Paraguay, } \\
\text { Peru, Uruguay }\end{array}$ & $\begin{array}{l}\text { Labor population } \\
\text { weighted average } \\
\text { for LAC-15 }\end{array}$ & $\begin{array}{l}\text { The decline in the skill premium has } \\
\text { been driven by a larger supply of } \\
\text { experienced and educated workers in } \\
\text { the region. }\end{array}$ \\
\hline $\begin{array}{l}\text { Campos et al. } \\
\text { (2012) }\end{array}$ & Mexico & Mexico & $\begin{array}{l}\text { Returns declined between } 1994 \text { and } \\
2006 \text {, due to changes in supply and, to }\end{array}$ \\
\hline
\end{tabular}

7 There is some evidence that due to the poor quality of education, however, the additional schooling induced by these conditional cash transfers programs may not result in a palpable increase in returns. 
a lesser extent, in demand; institutional factors were not relevant.

Barros et al. (2010);

Jaramillo and Saavedra (2010); Lopez-Calva and Lustig (2010)
Argentina, Brazil, Mexico, Peru

In Brazil, the fall in the skill premium seems to be caused both by changes in the composition of supply and demand as well as institutional factors, such as rising minimum wages. In Peru, it appears to be the result of the combined effect of an increase in the supply of workers with more years of schooling and the fact that demand for skilled workers did not outpace supply.

Gasparini and Lustig (2011); Lustig et al. (2013)

Argentina, Brazil, Mexico

Brazil, Mexico

Argentina, Brazil, Chile, Colombia, Gasparini et al. (2011)
Costa Rica, Ecuador,

El Salvador, Honduras, Mexico, Nicaragua, Panama, Uruguay, Venezuela
In both countries, the main driver of the decline in the skill premium was an increase in the relative supply of workers with high levels of education as a result of the educational upgrading that took place during the 1990s.

The skill premium rose in the 1990 s and shrunk in the 2000 s, within a context of a greater relative supply of skilled workers. This is consistent with an increase in the relative demand for skilled labor in the 1990s. Estimates of relative demand for the 2000 s indicate a reversal (except for Colombia and Costa Rica) in these trends, i.e., a negative shift in the relative demand for skilled labor in the 2000 s.

Not all studies find that the decline in the skill premium is the result of an increase in the supply of skilled workers, however. The study by Gasparini et al. (2011) for 16 countries in Latin America during 1989-2009 uses a partial equilibrium framework to study the supply and demand for labor. They assume a production function with an elasticity of substitution between skilled and unskilled labor (sigma) for different values ${ }^{8}$ and find that, more often than not, demand-side factors dominate supply-side factors in explaining the decline in skill premiums (Table 3).

\section{Table 3: Changes in the wage premium and the relative supply and demand for} skilled/unskilled workers

Annual \% change

\footnotetext{
${ }^{8}$ This study uses the methodology developed by Katz and Murphy (1992) and Goldin and Katz (2007), who formalized the Tinbergen's (1975) framework.
} 


\begin{tabular}{|c|c|c|c|c|c|c|c|c|}
\hline & \multicolumn{2}{|c|}{ Wage premium } & \multicolumn{2}{|c|}{ Relative supply } & \multicolumn{2}{|c|}{ Relative demand $(\sigma=2)$} & \multicolumn{2}{|c|}{ Relative demand $(\sigma=3)$} \\
\hline & 1990s & $2000 s$ & 1990s & $2000 s$ & 1990s & $2000 s$ & 1990s & $2000 s$ \\
\hline Argentina & 3.5 & -2.4 & 4.6 & 2.4 & 11.5 & -2.3 & 15.0 & -4.7 \\
\hline Bolivia & 7.9 & -4.6 & -0.2 & 5.1 & 15.6 & -4.1 & 23.5 & -8.7 \\
\hline Brazil & -0.4 & -3.2 & 1.6 & 4.4 & 0.8 & -1.9 & 0.4 & -5.1 \\
\hline Chile & 0.5 & -1.9 & 3.1 & 1.1 & 4.1 & -2.7 & 4.6 & -4.7 \\
\hline Colombia & 2.5 & -2.0 & 6.4 & 6.0 & 11.5 & 2.1 & 14.0 & 0.1 \\
\hline Costa Rica & 0.4 & -0.2 & 4.0 & 3.4 & 4.9 & 3.0 & 5.3 & 2.8 \\
\hline Ecuador & & -3.2 & & 3.4 & & -3.0 & & -6.3 \\
\hline El Salvador & 1.7 & -0.1 & 5.5 & -0.3 & 8.9 & -0.4 & 10.6 & -0.5 \\
\hline Honduras & 0.0 & -1.9 & 2.6 & 2.3 & 2.6 & -1.4 & 2.6 & -3.3 \\
\hline Mexico & 1.8 & -2.8 & 3.6 & 2.2 & 7.2 & -3.5 & 9.0 & -6.3 \\
\hline Nicaragua & 3.5 & -6.9 & 4.6 & 6.6 & 11.6 & -7.2 & 15.0 & -14.1 \\
\hline Panama & 0.3 & -2.3 & 2.3 & 2.4 & 2.9 & -2.2 & 3.1 & -4.4 \\
\hline Paraguay & 0.8 & -5.6 & 5.3 & 6.1 & 6.9 & -5.2 & 7.6 & -10.8 \\
\hline Peru & 0.6 & -2.8 & 0.2 & 3.8 & 1.3 & -1.8 & 1.9 & -4.6 \\
\hline Uruguay & 2.3 & -0.9 & 2.9 & 1.1 & 7.4 & -0.6 & 9.6 & -1.4 \\
\hline Venezuela & 1.1 & -4.8 & 3.9 & 4.2 & 6.2 & -5.4 & 7.3 & -10.3 \\
\hline Mean & 1.8 & -2.8 & 3.4 & 3.4 & 6.9 & -2.3 & 8.6 & -5.1 \\
\hline
\end{tabular}

Source: Gasparini et al. (2011), based on data from SEDLAC (CEDLAS and The World Bank).

An attempt to link these results to changing patterns in the composition of output, however, does not yield conclusive results. In an attempt to disentangle the importance of supply and demand factors, Gasparini et al. (2011) estimate a series of wage skill premium regressions. In the absence of an unambiguous indicator for relative demand, the authors use several proxies, including country and year fixed effects (which are assumed to capture the evolution of relative demand); unemployment rates of different skill groups (assumed to affect remuneration gaps between skill groups); an index of minimum wage levels, by country (assumed to capture the potential impact of labor market institutions on the wage skill premium); and an index of "net barter terms of trade" (assumed to capture the effect of international prices in the region on the wage skill premium). Among all of these, only the role of the terms of trade, which captures the effect of the recent boom in commodity prices, seems to support the demand-side hypotheses.

Along these lines, de la Torre et al. (2012) suggest that this boom in commodity prices appears to have played an important role by inducing a significant reallocation of labor from non-commodity tradeable sectors such as manufacturing, to sectors which are less intensive in skilled labor, such as services, which in turn reduced the skill premium and wage inequality. Nonetheless, Gasparini et al. (2011) show that despite the promising role played by the commodity boom, the patterns of employment by sector suggest a significant role for other forces.

For the six case studies included in his analysis, Cornia (2013) suggests that the drivers of the changes in the skill premium depended on the stagnation of demand for 
skilled labor during the 2000s; an increase in the supply of skilled workers following the surge in educational investments by governments during the 1990s and 2000s; an increase in the demand for unskilled workers due to the adoption of a more competitive exchange rate favoring the unskilled, labor-intensive tradeable sector; and a decline in the supply of unskilled labor due to rising educational attainment, a fall in birth rates and an increase in the rate of emigration. These results derive from a two-step approach in which changes over time in the Gini coefficient were first decomposed into changes in their 'proximate determinants', and then changes in the shares and concentration coefficients of labor, transfers, capital, and remittance income were correlated with their 'underlying determinants ${ }^{10}$. These results, however, cannot be taken as causal explanations due to endogeneity problems.

From a methodological point of view, it is not an easy task to determine whether demand or supply factors were predominant. A comparison of the results for Mexico between Gasparini et al. (2011) and Campos et al. (2012), for example, reveals that the results are overly sensitive to the age cohorts of workers, the period under study, and, above all, the elasticity of substitution between skilled and unskilled workers, which is very difficult to estimate in a robust manner (see, for example, the discussion by Manacorda et al., 2010). This is an area in which further research may prove useful, using alternative methods to estimate the elasticity of substitution in order to disentangle the contribution of demand and supply factors more precisely and robustly.

As mentioned above, another factor that could explain the decline in the returns to education is a degradation in the quality of tertiary education. The average (relative) returns to tertiary education could have fallen because, as its coverage expanded, either the quality of the marginal institution or the quality of the marginal student or both were lower. Yamada and Castro (2012) find evidence that supports the positive relationship between the quality of education and the returns to schooling in Peru. They likewise observed that the "convexification" of the wage profile as a consequence of the low quality of basic education and the better quality of tertiary education, began reversing starting in the 2000s.

\footnotetext{
${ }^{9}$ Depending on the country, the decomposition methods used were those proposed by Lerman and Yitzaki (1985), Milanovic (1998), and Bourguignon et al. (2005).

10 The second step follows a least square dummy variables (LSDV) model to correlate the Gini coefficient with a set of explanatory variables, including indicators of external economic conditions, economic growth; distribution of human capital; taxes and public expenditure; minimum wage; real exchange rate; and democracy.
} 
As documented by the authors, that finding is consistent with the decreasing quality of basic and tertiary education observed during the last ten years, as well as with the lower rate of increase in real wages for skilled workers compared to unskilled workers observed since the 2000s. Preliminary estimates for Mexico, however, do not find such evidence. Using a completely different approach, Urzua et al. (2013) find that a significant proportion between 35 and 42 percent, depending on the degree and the institution - of graduates from tertiary education obtain negative net economic returns. These findings, complemented with data for income which show that the gap between the cost and the benefits of tertiary education depend on the quality of tertiary education (World Bank 2011), suggest that the quality of certain types of tertiary education has decreased the skill premium in Chile.

\section{Summing Up}

During the 2000s, inequality in Latin America declined in the majority of countries for which a comparison can be made. The decline was statistically significant and significant in terms of the order of magnitude. On average, the decline in inequality accounted for about a third of the decline of the decline in extreme poverty (the remaining two-thirds were accounted for by economic growth).

The two main explanations for the decline in inequality are a reduction in hourly labor income inequality, and higher and more progressive government transfers. The fall in hourly labor income inequality, in turn, is explained by the reduction in the returns to education. Whether the latter is predominantly the result of an increase in the supply of workers with more educational attainment or a decline in the demand of workers with higher skills, has not been unequivocally established.

While not discussed in this paper, some authors have linked the rise of pro-poor government transfers to the process of democratization and Latin America's turn to the left. 11

11 See, for example, Robinson (2010), Cornia (2010) and Huber and Stephens (2012). 


\section{References}

Azevedo, J. P., M. E. Dávalos, C. Diaz-Bonilla, B. Atuesta, and R. A. Castañeda (2013) "Fifteen Years of Inequality in Latin America: How Have Labor Markets Helped?" Policy Research Working Paper 6384, The World Bank.

Azevedo, J. P., G. Inchauste, and V. Sanfelice (2012) "Decomposing the Recent Inequality Decline in Latin America", Mimeo, The World Bank.

Barros, R., M. N. Foguel, and G. Ulyssea (2006) Desigualdade de renda no Brasil: uma análise da queda recente (Vol. 1). Brasília: IPEA.

Barros, R., M. De Carvalho, S. Franco, and R. Mendonca (2010) "Markets, the State and the Dynamics of Inequality in Brazil”, in: L. F. Lopez-Calva, and N. Lustig (Eds.), Declining Inequality in Latin America: A Decade of Progress? Washington, D.C.: Brookings Institution and UNDP.

Bourguignon, F., F. H. G. Ferreira, and N. Lustig (Eds.) (2005) The Microeconomics of Income Distribution Dynamics in East Asia and Latin America, Washington, D.C.: The World Bank-Oxford University Press.

Campos, R., G. Esquivel, and N. Lustig (2012) "The Rise and Fall of Income Inequality in Mexico, 1989-2010”, UNU-WIDER, Working Paper No. 2012/10.

Castro, J. F., and G. Yamada (2012) “'Convexification' and 'Deconvexification' of the Peruvian Wage Profile: A Tale of Declining Education Quality", Working Paper DD/12/02, Universidad del Pacífico.

Cornia, A. (2013) "Inequality Trends and their Determinants: Latin America over 1990 2010", in Cornia, A. (Ed.), Falling Inequality in Latin America: Policy Changes and Lessons, Oxford University Press.

Cornia, A. (2010) “Income Distribution under Latin America's New Left Regimes”, Journal of Human Development and Capabilities, 11(1), 85-114.

Cruces, G., C. Garcia-Domenech, and L. Gasparini (2011) "Inequality in Education. Evidence for Latin America", UNU-WIDER, Working Paper No. 2011/93.

Datt, G., and M. Ravallion (1992) "Growth and Redistribution Components of Changes in Poverty Measures: A Decomposition with Applications to Brazil and India in the 1980s. Journal of Development Economics, 38, 275-295.

De la Torre, A, J. Messina, and S. Pienknagura (2012) “The Labor Market Story Behind Latin America's Transformation", Semiannual Report, Regional Chief Economist Office, Latin America and the Caribbean, The World Bank. 
Esquivel, G., N. Lustig, and J. Scott (2010) “A Decade of Falling Inequality in Mexico:

Market Forces or State Action?” in: L. F. Lopez Calva, and N. Lustig (Eds.), Declining Inequality in Latin America: A Decade of Progress? Washington, D.C.: Brookings Institution and UNDP.

Gasparini, L., and G. Cruces (2010) "A Distribution in Motion: The Case of Argentina", in: L. F. Lopez-Calva, and N. Lustig (Eds.), Declining Inequality in Latin America: A Decade of Progress? Washington, D.C.: Brookings Institution and UNDP.

Gasparini, L., and N. Lustig (2011) "The Rise and Fall of Income Inequality in Latin America", Working Paper 1110, Tulane University.

Gasparini, L., S. Galiani, G. Cruces, and P. Acosta (2011) "Educational Upgrading and Returns to Skills in Latin America. Evidence from a Supply-Demand Framework, 1990-2010”. Policy Research Working Paper 5921, The World Bank.

Goldin, C., and L. Katz (2007) “The Race Between Education and Technology: The Evolution of U.S. Educational Wage Differentials, 1890 to 2005”, NBER Working Paper No. 12984.

Huber, E. and J. D. Stephens (2012) Democracy and the Left: Social Policy and Inequality in Latin America, University of Chicago Press.

Jaramillo, M., and J. Saavedra (2010). "Inequality in Post-structural Reform Peru: The Role of Market and Policy Forces", in: Luis F. Lopez-Calva, and N. Lustig (Eds.), Declining Inequality in Latin America: A Decade of Progress? Washington, D.C.: Brookings Institution and UNDP.

Katz, L., and K. Murphy (1992) “Changes in Relative Wages, 1963-1987: Supply and Demand Factors", Quarterly Journal of Economics, 107, 35-78.

Lerman, R. I., and S. Yitzhaki (1985) "Income Inequality Effects by Income Source. A New Approach and Applications to the United States", Review of Economics and Statistics, 67, 151-156.

Lopez-Calva, L. F., and N. Lustig (Eds.), Declining Inequality in Latin America: A Decade of Progress? Washington, D.C.: Brookings Institution and UNDP.

Lustig, N., and C. Pessino (2013) "Social Spending and Income Redistribution in Argentina in the 2000s: the Rising Role of Noncontributory Pensions", CEQ Working Paper No. 5.

Lustig, N, L. F. Lopez Calva, E. Ortiz-Juarez (2013) "Declining Inequality in Latin America in the 2000s: The Cases of Argentina, Brazil, and Mexico", World Development, 44, 129-141. 
Manacorda, M., C. Sánchez-Páramo, and N. Schady (2010) "Changes in Returns to Education in Latin America: The Role of Demand and Supply of Skills", Industrial and Labor Relations Review, 63, 307-326.

Milanovic, B. (1998) “Explaining the Increase in Inequality during the Transition”, Policy Research Working Paper 1935, The World Bank.

Reyes, L., J. Rodríguez, and S. S. Urzúa (2013) "Heterogeneous Economic Returns to Postsecondary Degrees: Evidence from Chile”, NBER Working Paper No. 18817.

Robinson, J. A. (2010) “The Political Economy of Redistributive Policies”, in: Luis F. Lopez-Calva, and N. Lustig (Eds.), Declining Inequality in Latin America: A Decade of Progress? Washington, D.C.: Brookings Institution and UNDP.

Tinbergen, J. (1975) Income Distribution: Analysis and Policies, North-Holland: Amsterdam. World Bank (2011) Chile's State-Guaranteed Student Loan Program (CAE), Washington D.C.: The World Bank. 